\title{
Editorial: Ecological Development and Functioning of Biological Soil Crusts After Natural and Human Disturbances
}

\author{
Maik Veste ${ }^{1,2 *}$, Vincent John Martin Noah Linus Felde ${ }^{3}$, Steven D. Warren ${ }^{4}$ and \\ Nicole Pietrasiak ${ }^{5}$ \\ ${ }^{1}$ Institute of Environmental Science, Brandenburg University of Technology Cottbus-Senftenberg, Cottbus, Germany, \\ ${ }^{2}$ CEBra - Centre for Energy Technology Brandenburg e.V., Cottbus, Germany, ${ }^{3}$ Institute of Soil Science, Leibniz University of \\ Hannover, Hannover, Germany, ${ }^{4}$ Rocky Mountain Research Station, United States Forest Service (USDA), Fort Collins, CO, \\ United States, ${ }^{5}$ Department of Plant and Environmental Sciences, New Mexico State University Las Cruces, Las Cruces, \\ NM, United States
}

Keywords: ecosystem development, initial ecosystems, cyanobacteria, mosses, lichens, soil-plant systems, biocrusts, restoration

\section{Editorial on the Research Topic}

\section{Ecological Development and Functioning of Biological Soil Crusts After Natural and Human} Disturbances

In recent years, the importance of soil health for ecosystem functions has come further into the scientific focus (Lehmann et al., 2020). Especially after severe ecosystem disturbances, soil formation has to start anew. Such disturbances, which reset ecosystem development to the starting point, can be of natural (volcanoes, mobile sand dunes, floods, glaciers) (La Farge et al., 2013; Lan et al., 2014) or human origin (post-mining landscapes, military training areas, agricultural lands) (Belnap et al., 2007; Schaaf et al., 2011). In these young ecosystems, the interactions between the initial colonizers, the inorganic matter, and the subsequent biogeochemical processes are an important prerequisite for the development of elemental fluxes, soil genesis, and thus for further ecosystem development. In addition to pioneer plants, photoautotrophic and heterotrophic microorganisms play a major role in the colonization of the freshly deposited sediment, regolith, or disturbed soil material. Biological soil crusts (BSCs) develop when various combinations of diminutive bacteria, terrestrial algae, fungi, lichens, and/or bryophytes occupy the upper few millimeters of the soil or regolith. They can be present in a wide range of ecological, including successional, and climatic conditions (Figure 1, Colesie et al., 2016) when and where disturbance and/or aridity have resulted in bare soil available for colonization. However, they are most prevalent in arid, semi-arid, and polar ecosystems and in temperate dry grasslands where vascular plant cover and diversity are characteristically low, leaving large areas available for colonization by some combination of the organismal groups mentioned above (Weber et al., 2016). The ecological roles of BSCs are numerous and diverse including the collection, accumulation, cycling of essential airborne and soil nutrients (Beraldi-Campesi et al., 2009), redistribution of precipitated water (Chamizo et al., 2016), soil formation and stabilization (Lan et al., 2014). Various ecological studies on the development and ecosystem functioning of BSCs have been conducted during the last three decades (Belnap and Lange, 2003; Breckle et al., 2008; Weber et al., 2016). The nexus of science related to BSCs and aerobiology strongly suggests that BSCs can become established or re-established via naturally occurring processes (Condon et al., 2020), as BSC propagules are found naturally in the atmosphere (Elliott et al., 2019), and can be transported very long distances between hemispheres, 


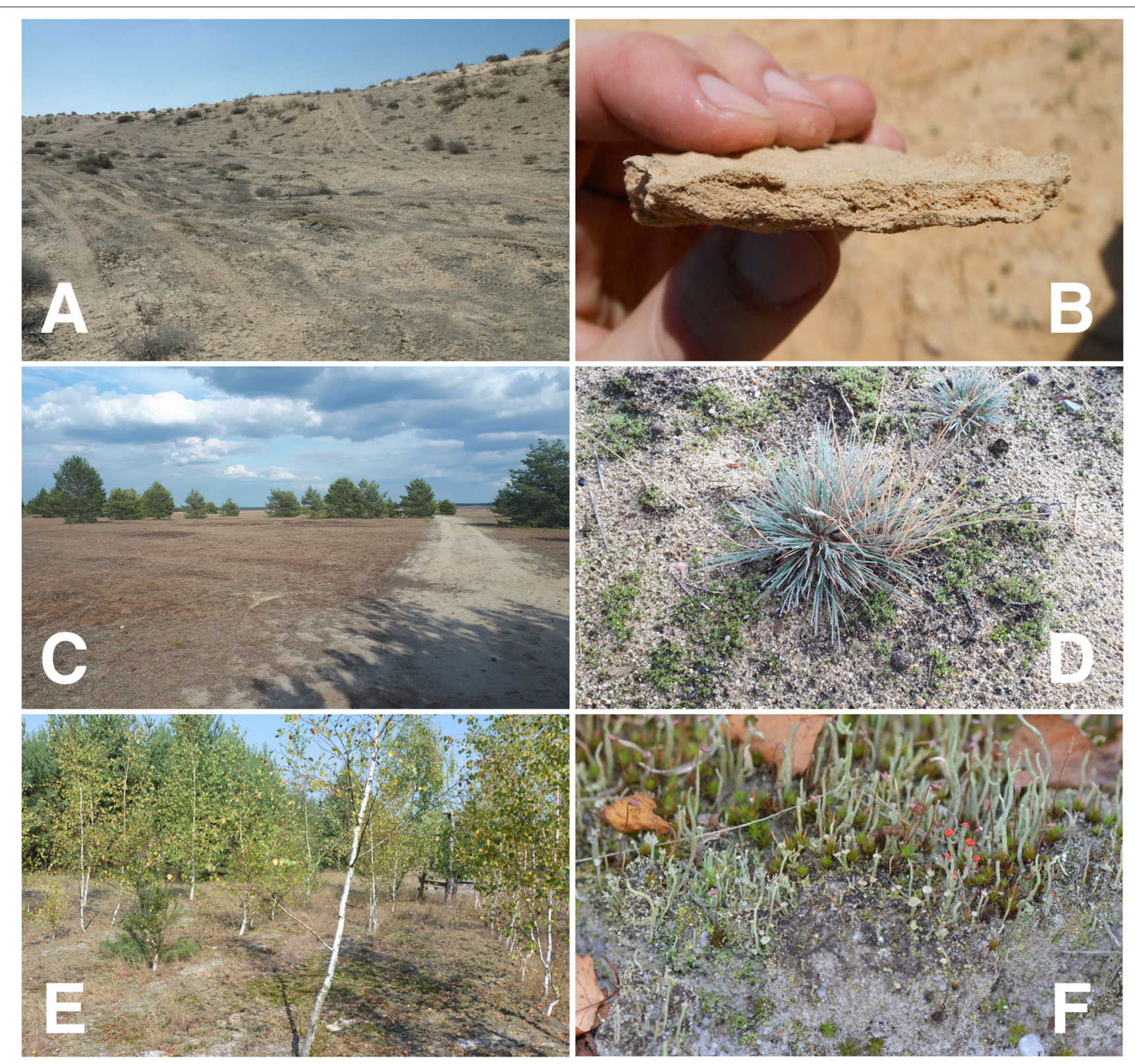

FIGURE 1 | Examples of different BSC in disturbed ecosystems (A) Biological soil crusts re-covered after disturbance by military vehicles in the Nizzana arid dunes of the north-western Negev, Israel, (B) Multi-layered cyanobacterial BSC in Nizzana, (C) Soil lichens- and moss-dominated BSC covering large areas of the sandy soils in a temperate dry grassland in a formerly disturbed military training area (Lieberoser Heide, Brandenburg, NE Germany), (D) Early successional stages of green algae and moss BSC established around gray hair-grass (Corynephorus canescens) in a temperate dry grassland, (E) Reclaimed post-mining site in Schlabendorf, Brandenburg, Germany is covered by soil lichen-moss communities mainly Cladonia spec. (F) (Gypser et al., 2015).

continents, and climates (Warren et al., 2019). Even after drastic disturbances, like fires, the relatively fast recovery of microorganisms can be observed (Dümig et al., 2014; Aanderud et al.; Chamizo et al., 2020). The ability of selected BSC organisms to recover quickly after disturbance can be exploited for various applications in ecosystem restoration (Gypser et al., 2015; Antoninka et al., 2020; Román et al., 2020). The speed and efficiency of inducing land surface stability (which is a prerequisite for soil development) depends on various environmental conditions (like texture and climate) (Chamizo et al., 2018) and may hence be very site specific. However, fast recovery is not always happen for all BSC organisms in all ecosystems. Under very harsh conditions such as the hyper-arid desert, this is not the case and recovery can be very slow. Here cyanobacteria and lichen biocrusts also need a longer time to establish after disturbance. All these studies in the different ecosystems underline the importance of the BSCs 
for the biogeochemical and ecohydrological processes in the soil-plant system.

There remains a gap in understanding what shapes the globally heterogeneous biogeographical patterns of the different BSC organisms and how they relate to ecological processes surrounding the establishment, re-establishment, and development of BSCs. A more complete understanding of similarities and dissimilarities in the establishment, growth, and regeneration of BSCs from different geographical regions is essential to fully comprehend their contribution to ecosystem functioning and exploit their potential to improve the health of diverse soils. This is especially true for (remote) geographical regions that have hitherto been understudied, such as the Brazilian Caatinga, for which Szyja et al. emphasized the ecological importance of BSCs for providing ecosystem services.

In the recent decade, new research aimed to link the structure of BSC communities with ecosystem processes. Warren et al. provide an overview of how each organismal group contributes to the formation and maintenance of the structural and functional attributes of BSCs, how they reproduce, and how they are dispersed. The introduction of molecular biological methods (Keepers et al.) provided new insights into the function and composition of BSC communities in different ecosystems and climatic regions. Molecular biological studies in drylands in the Mojave Desert (Fisher et al.), Central Mexico (Becerra-Absalón et al.), Brazilian savanna (Machado-de-Lima et al.), and the arid lands of Western Australia (Autumn et al.) shed light on the composition of BSC communities and discussed their possible roles within their respective ecosystems. Pushkareva et al. examined differences in community composition and biomass in Arctic soil systems. An unusual human-made ecosystem is described by Sommer et al. that demonstrated how green algae, cyanobacteria, and diatoms can establish on severely saline mine tailings in Germany.

Still, the complex interspecific interactions between the organisms in the BSC communities and how these are influenced by the environment are not fully understood. Especially, the implication of heterogeneity and microhabitats on biogeochemical processes and plant-microbes (BSCs)-soil interactions need to be explored furthermore. In this context, Albright et al. show that microhabitat (e.g., vascular plant

\section{REFERENCES}

Antoninka, A., Faist, A., Rodriguez-Caballero, E., Young, K. E., Chaudhary, V. B., Condon, L. A., et al. (2020). Biological soil crusts in ecological restoration: emerging research and perspectives. Restoration Ecol. 28, 3-8. doi: $10.1111 /$ rec.13201

Belnap, J., and Lange, O. L. (eds.). (2003). Biological Soil Crusts: Structure, Function and Management. Ecological Studies 150. Heidelberg: Springer. Available online at: https://rd.springer.com/book/10.1007/978-3-642-56475-8

Belnap, J., Phillips, S. L., Herrick, J. E., and Johansen, J. R. (2007). Wind erodibility of soils at Fort Irwin, California (Mojave Desert), USA, before and after trampling disturbance: implications for land management. Earth Surface Processes Landforms 32, 75-84. doi: 10.1002/esp. 1372 rhizosphere, BSC, and below BSC) was the strongest driver of differences in bacterial and fungal community richness, diversity, and composition in a dryland grassland in North America. The study by Condon and Pyke shows the importance of BSC organisms in plant communities of the semi-arid western US and argues that they should be included in ecological site descriptions due to their important contributions to ecosystem functions. The dominant components of biological crusts are photoautotrophic organisms, which primarily provide carbon for heterotrophs. More complex is the importance of the biological crusts for the $\mathrm{N}$-cycling. Their ability to biologically fix $\mathrm{N}$ makes them an important $\mathrm{N}$ input pathway into nutrient-poor soils, and large amounts of inorganic $\mathrm{N}$ become accessible to the soil biota through the initial activity of the $\mathrm{N}$-fixers. The interactive effects of BSC successional state and exposure to warmer temperatures on the rate and temperature sensitivity of soil heterotrophic $\mathrm{C}$ and $\mathrm{N}$ cycling in laboratory incubations could be shown in a mesocosm experiment under greenhouse conditions by Tucker et al.. The ecophysiological adaptation strategy and desiccation tolerance (Greenwood et al.) of BSC mosses are most crucial for their development in these extreme habitats, and furthermore during global warming. The study by Borchhardt and Gründling-Pfaff shows the ecophysiological plasticity of Klebsormidium to temperature in biological soil crusts from the Arctic and Antarctica.

Open topics for BSC research are still the interactions and feedbacks of biogeochemical processes between microorganisms and the soil-plant system. This applies particularly to the impact of climate change on the development of biological soil crusts.

\section{AUTHOR CONTRIBUTIONS}

MV organized the Research Topic together with VF, SW, and NP. All authors contributed to the article and approved the submitted version.

\section{ACKNOWLEDGMENTS}

We thank all authors for their contributions, the reviewers for valuable comments, and the Frontiers Editorial Office for improving the layout of this Research Topic.

Beraldi-Campesi, H., Hartnett, H. E., Anbar, A., Gordon, G. W., and Garcia-Pichel, F. (2009). Effect of biological soil crusts on soil elemental concentrations: implications for biogeochemistry and as traceable biosignatures of ancient life on land. Geobiology 7, 348-359. doi: 10.1111/j.1472-4669.2009.00204.x

Breckle, S.-W., Yair, A., and Veste, M. (eds.). (2008). Arid Dune Ecosystems - The Nizzana Sands in the Negev Desert. Ecological Studies 200. Heidelberg: Springer. Available online at: https://www.springer.com/de/book/9783540754978

Chamizo, S., Belnap, J., Eldridge, D. J., Cantón, Y., and Malam Issa, O. (2016). “The role of biocrusts in arid land hydrology," in Biological Soil Crusts: An Organizing Principle in Drylands, Ecological Studies 226, eds B. Weber, B. Büdel, and J. Belnap (Cham: Springer International Publishing), 321-346. Available online at: http://link.springer.com/10.1007/978-3-319-30214-0_17

Chamizo, S., Mugnai, G., Rossi, F., Certini, G., and De Philippis, R. (2018). Cyanobacteria inoculation improves soil stability and fertility on different 
textured soils: gaining insights for applicability in soil restoration. Front. Environ. Sci. 6:49. doi: 10.3389/fenvs.2018.00049

Chamizo, S., Adessi, A., Giacomo, C., and De Philippis, R. (2020). Cyanobacteria inoculation as a potential tool for stabilization of burned soils. Restoration Ecol. 28, S106-S114. doi: 10.1111/rec.13092

Colesie, C., Felde, V. J. M. N.L., and Büdel, B. (2016). "Composition and macrostructure of biological soil crusts," in Biological Soil Crusts: An Organizing Principle in Drylands, Ecological Studies 226, eds B. Weber, B. Büdel, and J. Belnap (Cham: Springer International Publishing), 159-172. Available online at: http://link.springer.com/10.1007/978-3-319-30214-0_9

Condon, L. A., Pietrasiak, N., Rosentreter, R. and Pyke, D. A. (2020), Passive restoration of vegetation and biological soil crusts following 80 years of exclusion from grazing across the Great Basin. Restoration Ecology 28, S75-S85. doi: $10.1111 /$ rec. 13021

Dümig, A., Veste, M., Hagedorn, F., Fischer, T., Lange, P., Spröte, R., et al. (2014). Water-soluble organic matter from biological soil crusts induces initial formation of sandy temperate soils. Catena 122, 196-208. doi: 10.1016/j.catena.2014.06.011

Elliott, D. R., Thomas, A. D., Strong, C. L., and Bullard, J. (2019). Surface stability in drylands is influenced by dispersal strategy of soil bacteria. J. Geophys. Res. Biogeosci. 124, 3403-3418. doi: 10.1029/2018JG004932

Gypser, S., Veste, M., Fischer, T., and Lange, P. (2015). Formation of soil lichens crusts at reclaimed post-mining sites, Lower Lusatia, North-east Germany. Graphis Scripta 27, 3-14. Available online at: http://nhm2.uio.no/botanisk/lav/ Graphis/27_1-2/GS_27_3.pdf

La Farge, C., Williams, K. H., and England, J. H. (2013). Regeneration of little Ice Age bryophytes emerging from a polar glacier with implications of totipotency in extreme environments. Proc. Natl. Acad. Sci. U.S.A. 110, 9839-9844. doi: 10.1073/pnas.1304199110

Lan, S., Zhang, Q., Wu, L., Liu, Y., Zhang, D., and Hu, C. (2014). Artificially accelerating the reversal of desertification: cyanobacterial inoculation facilitates the succession of vegetation communities. Environ. Sci. Technol. 48, 307-315. doi: $10.1021 /$ es403785j

Lehmann, J., Bossio, D. A., Kögel-Knabner, I., and Rillig, M. C. (2020). The concept and future prospects of soil health. Nat. Rev. Earth Environ. 1, 544-553. doi: 10.1038/s43017-020-0080-8

Román, J. R., Chilton, A. M., Cantón, Y., and Muñoz-Rojas, M. (2020). Assessing the viability of cyanobacteria pellets for application in arid land restoration. J. Environ. Manage. 270:110795. doi: 10.1016/j.jenvman.2020. 110795

Schaaf, W., Bens, B., Fischer, A., Gerke, H. H., Gerwin, W., Grünewald, U., et al. (2011). Patterns and processes of initial terrestrial-ecosystem development. J. Plant Nutr. Soil Sci. 174, 229-239. doi: 10.1002/jpln.2010 00158

Warren, S. D., St. Clair, L. L., and Leavitt, S. D. (2019). Aerobiology and passive restoration of biological soil crusts. Aerobiologia 35, 45-56. doi: 10.1007/s10453-018-9539-1

Weber, B., Büdel, B., and Belnap, J. (2016). Biological Soil Crusts: An Organizing Principle in Drylands. Ecological Studies 236. Heidelberg: Springer. Available online at: https://rd.springer.com/book/10.1007/978-3-319-30214-0

Conflict of Interest: The authors declare that the research was conducted in the absence of any commercial or financial relationships that could be construed as a potential conflict of interest.

Copyright $\odot 2021$ Veste, Felde, Warren and Pietrasiak. This is an open-access article distributed under the terms of the Creative Commons Attribution License (CC BY). The use, distribution or reproduction in other forums is permitted, provided the original author(s) and the copyright owner(s) are credited and that the original publication in this journal is cited, in accordance with accepted academic practice. No use, distribution or reproduction is permitted which does not comply with these terms. 